\title{
HUBUNGAN PENGEMBANGAN KAWASAN BISNIS DAN PARIWISATA TERPADU DI KOTA MAKASSAR TERHADAP KAWASAN PESISIR KECAMATAN GALESONG UTARA KABUPATEN TAKALAR
}

\author{
Khairul Fuady ${ }^{1}$, Fadhil Surur ${ }^{2}$ \\ 12) Jurusan Teknik Perencanaan Wilayah dan Kota \\ ${ }^{12)}$ UIN Alauddin Makasar \\ 2)fadhil.surur@uin-alauddin.ac.id
}

\begin{abstract}
Integrated business and tourism development in Makassar was an effort to utilize the potentials of the region in supporting the development activities. One of the areas that identified as having influence activities from the business and tourism area in Makassar City was North Galesong District. The area was located in the north and was approximately 27 kilometers from the capital of Takalar Regency. North Galesong District was one of the connecting routes to Akkarena Beach which was an alternative route for people from and headed to Makassar City. This study was aim to determine the relationship between the development of integrated business and tourism area in Makassar City and the coastal area in North Galesong District. Correlation analysis test was used to determine the effect of the development program. The pond, the number of fisherman, trade services and facilities, as well as road infrastructure were used as parameter. This study showed that the relationship between trade facilities and services and road infrastructure gave a positive contribution. The development of trade service activities and the increase in the length of roads were closely linked to the development of integrated business and tourism areas in Makassar City.
\end{abstract}

Keywords: business, toursim, coastal

\begin{abstract}
Abstrak
Pengembangan bisnis dan pariwisata terpadu di Kota Makassar merupakan salah satu upaya untuk memanfaatkan segala potensi kawasan dalam menunjang kegiatan pengembangan. Salah satu wilayah yang teridentifikasi memiliki aktivitas pengaruh dari kawasan bisnis dan pariwisata Kota Makassar adalah Kecamatan Galesong Utara, wilayahnya terletak di sebelah utara dan berjarak kurang lebih 27 kilometer dari ibu kota Kabupaten Takalar. Kecamatan Galesong Utara merupakan salah satu jalur penghubung menuju Pantai Akkarena yang menjadi rute alternatif masyarakat dari dan menuju Kota Makassar. Tujuan penelitian ini adalah untuk mengetahui hubungan antara pengembangan kawasan bisnis dan pariwisata terpadu Kota Makassar terhadap kawasan pesisir Kecamatan Galesong Utara. Untuk mengetahui pengaruh pengembangan digunakan analisis uji korelasi dengan 4 parameter yaitu lahan tambak, jumlah nelayan, sarana perdagangan dan jasa serta prasarana jalan. Hasil dari penelitian ini bahwa diperoleh hubungan antara sarana perdangan/jasa dan prasarana jalan memberikan kontribusi yang positif. Perkembangan aktivitas perdagangan/jasa dan peningkatan panjang jalan berhubungan erat dari kegiatan pembangunan kawasan bisnis dan pariwisata terpadu di Kota Makassar.
\end{abstract}

Kata Kunci : bisnis, wisata, pesisir

\section{Pendahuluan}

Kawasan pesisir dikenal sebagai ekosistem perairan yang memiliki potensi sumberdaya yang sangat besar. Sumberdaya alam pesisir merupakan salah satu sumberdaya alam yang terdapat di Indonesia dan memiliki potensi tinggi untuk dikembangkan. Wilayah pesisir telah banyak dimanfaatkan dan memberikan sumbangan yang berarti bagi peningkatan taraf hidup masyarakat di kawasan pesisir. Sejalan dengan pertambahan penduduk dan peningkatan kegiatan pembangunan sosial ekonomi wilayah pesisir terus bertambah. Konsekuensi dari tekanan terhadap pesisir ini adalah masalah pengelolaan yang timbul karena berbagai kepentingan yang ada di wilayah pesisir (Purnamasari, 2015).
Pariwisata merupakan suatu bidang yang potensial dalam pembangunan suatu Negara. Daerah dengan potensi pariwisata dapat menghidupkan kegiatan ekonomi masyarakat sekitar dengan timbulnya usaha-usaha skala kecil sampai menengah, mengurangi tingkat pengangguran, meningkatkan pendapatan masyarakat, serta meningkatkan Pendapatan Asli Daerah (PAD) yang akan kembali digunakan oleh pemerintah untuk melaksanakan pembangunan di daerah dan mencapai kesejahteraan (Riyaningtiyas, 2014). Kawasan pesisir Kota Makassar yang memiliki arti strategis untuk pengembangan wisata bahari karena berbatasan langsung dengan Selat Makassar, sehingga memiliki potensi sumberdaya alam (pantai berpasir atau mangrove) dan jasa-jasa 
lingkungan yang berpotensi untuk pengembangan wisata bahari seperti potensi wisata pantai, wisata mangrove, wisata budaya, dan wisata sejarah yang beragam, menarik dan cukup terkenal. Jenis wisata yang dikembangkan saat ini di kawasan pesisir dan laut Kota Makassar secara langsung adalah: wisata Pantai Losari, Pantai Akkarena, Pantai Tanjung Bunga, dengan kegiatan wisata seperti berperahu, berenang, memancing serta olahraga pantai, berjemur, dan piknik menikmati atmosfer laut. Wisata theme park dan out bound yang ada disini adalah di Trans Studio dan Pantai Akkarena (DKP Kota Makassar 2010; Dinas Pariwisata Kota Makassar, 2010).

Salah satu wilayah yang teridentifikasi memiliki aktivitas pengaruh dari wisata Pantai akkarena adalah Kecamatan Galesong Utara, wilayahnya terletak di sebelah utara dan berjarak kurang lebih 27-kilometer dari ibu kota Kabupaten Takalar. Kecamatan Galesong Utara merupakan salah satu jalur penghubung menuju Pantai Akkarena. Sehingga menjadi rute alternatif masyarakat dari dan menuju Kota Makassar. Dampak yang ditandai dengan perubahan penggunaan lahan, peningkatan aktivitas masyarakat hingga isu-isu kerusakan lingkungan.

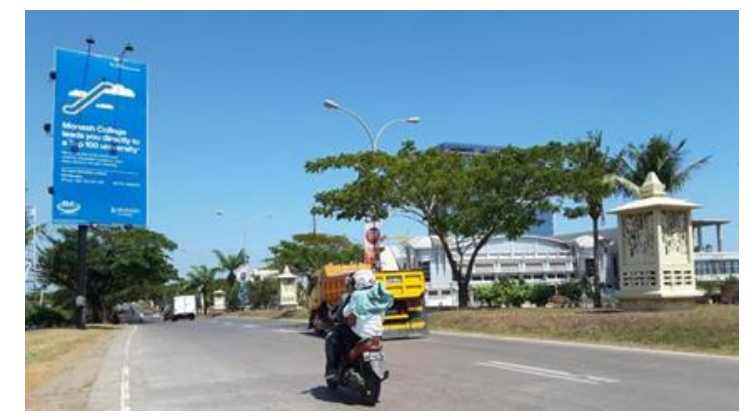

Gambar 1. Kawasan bisnis dan pariwisata terpadu

Kondisi tersebut menyebabkan kawasan Bisnis dan Pariwisata Terpadu Kota Makassar semakin didorong untuk meningkatkan kualitas kawasan dengan pembangunan dan perbaikan sarana serta prasarana penunjang wisata. Di sisi lain peran serta masyarakat dan pemerintah sangat diperlukan untuk menjaga kelestarian lingkungan objek pariwisata dengan pengoptimalan perawatan lingkungan dan pengawasan. Berdasarkan latar belakang tersebut, maka rumusan permasalahan penelitian ini adalah bagaimana pengaruh dan strategi pengembangan kawasan bisnis dan pariwisata terpadu Kota Makassar terhadap kawasan Pesisir Kecamatan Galesong Utara Kabupaten Takalar. Adapun tujuan penelitian ini adalah untuk mengetahui pengaruh dan menyusun strategi pengembangan kawasan bisnis dan pariwisata terpadu Kota Makassar terhadap kawasan pesisir Kecamatan Galesong Utara

\section{Metode Penelitian}

Lokasi objek penelitian penulis yaitu Kawasan Bisnis dan Pariwisata Terpadu Kota Makassar dan Kecamatan Galesong Utara Kabupaten Takalar.
Lokasi tersebut merupakan Kawasan wisata di Kota Makassar yang memiliki potensi baik dari segi fisik, aksesibilitas, partisipasi masyarakat serta sarana dan prasarana daya tarik wisata. Adapun waktu penelitian dilakukan pada bulan Oktober hingga November 2017.

Teknik pengumpulan data mencakup obervasi lapangan, kuesioner, wawancara, metode insational dan telaah pustaka. Pengambilan sampel pada penelitian ini menggunakan teknik purposive sampling, yaitu menurut Sugiyono (2001) menyatakan bahwa sampling purposive adalah teknik penentuan sampel dengan pertimbangan tertentu. Jumlah masyarakat yang akan dijadikan informan dalam penelitian adalah menggunakan pendekatan purposive sampling yaitu sebanyak 10 orang dalam hal ini peneliti memilih sampel orangorang yang terlibat langsung dengan dunia pariwisata dan pesisir dalam jangka waktu yang cukup lama, terlibat dalam bidang tata ruang, memiliki pengetahuan terkait lokasi penelitian dan pernah mengunjungi lokasi penelitian. Sampel yang digunakan dalam penelitian ini terdiri dari: Pihak pemerintah (Dinas Kelautan dan Perikanan, Bappeda, dam Dinas Pariwisata), Akademisi (Dosen dengan bidang terkait), dan masyarakat sekitar.

Metode analisis data yang digunakan adalah analisis uji korelasi yang merupakan salah satu cara untuk mengkaji keterkaitan antara faktor yang berpengaruh antara koefisien korelasi (r). Analisis ini digunakan untuk menjawab tujuan penelitian pertama (pengaruh kawasan bisnis dan pariwisata terpadu terhadap kawasan pesisir). Rumus umum dari uji korelasi yaitu :

$$
\mathrm{r}=\sqrt{\frac{N \cdot \sum x y-\sum x \cdot \Sigma_{y}}{\left[N \Sigma_{x} 2-\left(\sum x\right)^{2}\right]\left[N \cdot \Sigma_{y}^{2}-\left(\Sigma_{y}\right)^{2}\right]}}
$$

Keterangan :

$\mathrm{N}=$ Jumlah perlakuan (pengambilan data)

$\mathrm{X} 1$ = lahan tambak

$\mathrm{X} 2=$ nelayan

$\mathrm{X} 3=$ perdagangan dan jasa

$\mathrm{X} 4=$ jalan

Y 1 = lahan terbangun

Dengan Asumsi

- Jika $\mathrm{r}=0$ atau mendekati 0, maka hubungan antara kedua variabel sangat lemah atau tidak ada pengaruh.

- Jika r mendekati 0,5 maka hubungan kedua variabel sedang atau berpengaruh.

- Jika $\mathrm{r}=0,5$ atau mendekati 1 maka hubungan kedua variabel sangat kuat atau sangat berpengaruh

\section{Hasil dan Pembahasan}

Penggunaan Lahan Pada Tahun 2000

Kota Makassar secara administratif berkedudukan sebagai Ibu Kota Provinsi Sulawesi 
Selatan dan sebagai pusat perkembangan dan pelayanan pembangunan. Secara geografis Kota Makassar selain sebagai pusat pengembangan dan pelayanan pembangunan di kawasan Timur Indonesia dengan ketinggian yang bervariasi antara $0-25 \mathrm{M}$ dari permukaan laut, dengan suhu udara antara 22 " C sampai dengan $32^{\circ} \mathrm{C}$ dan curah hujan antara 2000-3000 $\mathrm{mm}$ dengan hari hujan rata-rata 108 hari pertahun. Adapun batas-batas administrasi Kota Makassar sebagai berikut:

- Sebelah Utara berbatasan dengan Kabupaten Pangkajene Kepulauan

- Sebelah Timur berbatasan dengan Kabupaten Maros.

- Sebelah Selatan berbatasan dengan dengan Kabupaten Gowa.

- Sebelah Barat berbatasan dengan Selat Makassar

Kawasan bisnis dan pariwisata terpadu Kota Makassar direncanakan dalam wilayah di wilayah Tanjung Bunga Kecamatan Tamalate. Pelaksanaan kawasan ini diarahkan berdasarkan ketetepan dalam Perda Nomor 6 Tahun 2006 Tentang RTRW, oleh karena dari tiga usaha bisnis dan pariwisata (bisnis karamba, akarena, dan tanaman hias). Berdasarkan perkembangan di kawasan bisnis dan pariwisata terpadu di Kota Makassar berdampak langsung terhadap wilayah di sekitarnya salah satunya Kecamatan Galesong Utara.

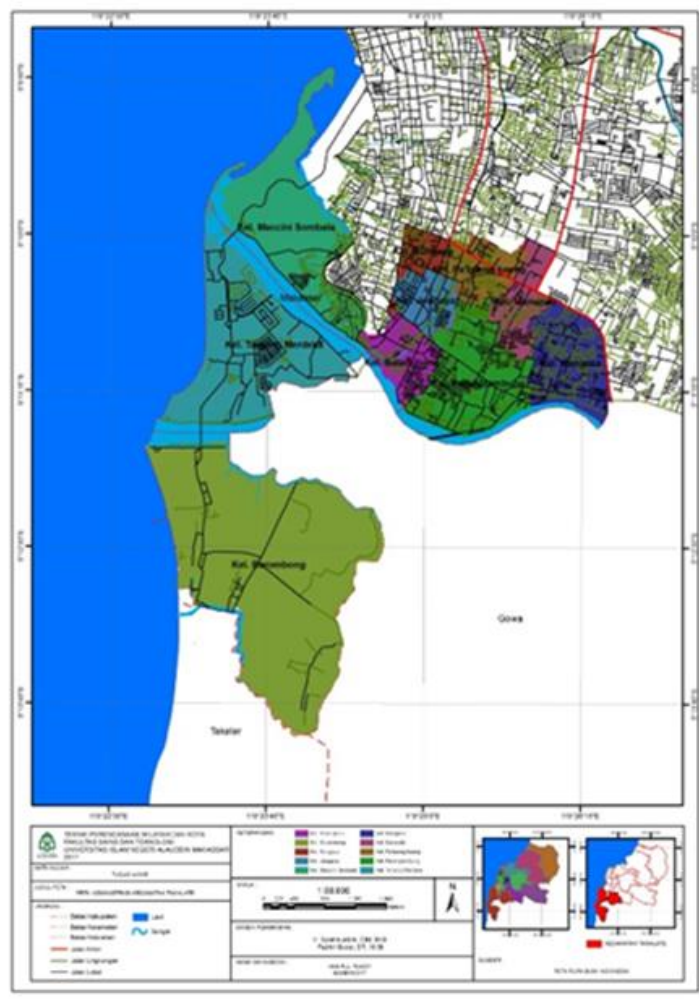

Gambar 2. Peta Kecamatan Tamalate

Perkembangan kawasan bisnis dan pariwisata terpadu membuka jalur atau akses alternatif dari Kecamatan Galesong Utara di Kabupaten Takalar dari dan menuju Kota Makassar. Dampak nyata dari pengaruh aktivitas bisnis adalah berubahnya kondisi sebagian besar wilayah Kecamatan Galeong Utara menjadi lahan terbangun. Rentang tahun 2014 2015 tidak terjadi penambahan luasan lahan, dimana masih tetap pada angka 877,61 ha, sedangkan pada tahun 2016 terjadi pertambahan luasan menjadi 878,32 ha. Pertambahan lahan terbangun dimanfaatkan untuk kegiatan permukiman, perdagangan jasa dan pariwisata sebagai dampak dari kegiatan pengembangan kawasan bisnis dan parwisata terpadu di Kota Makassar.

Galesong Utara sebagai salah satu kecamatan yang terletak disebelah utara dan berjarak kurang lebih 27 kilometer dari ibukota Kabupaten Takalar. Ibu kota Kecamatan Galesong Utara terletak di Kelurahan Bontolebang yang sebelah utara berbatasan dengan Kota Makassar, sebelah timur berbatasan dengan Kabupaten Gowa, sebelah selatan berbatasan dengan Kecamatan Galesong dan sebelah barat berbatasan dengan Selat Makassar. Luas Wilayah Kecamatan Galesong Utara sekitar $15,11 \mathrm{~km}^{2}$ atau sebesar 2,67 persen dari total Kabupaten Takalar yang memiliki 9 desa dan 1 kelurahan.

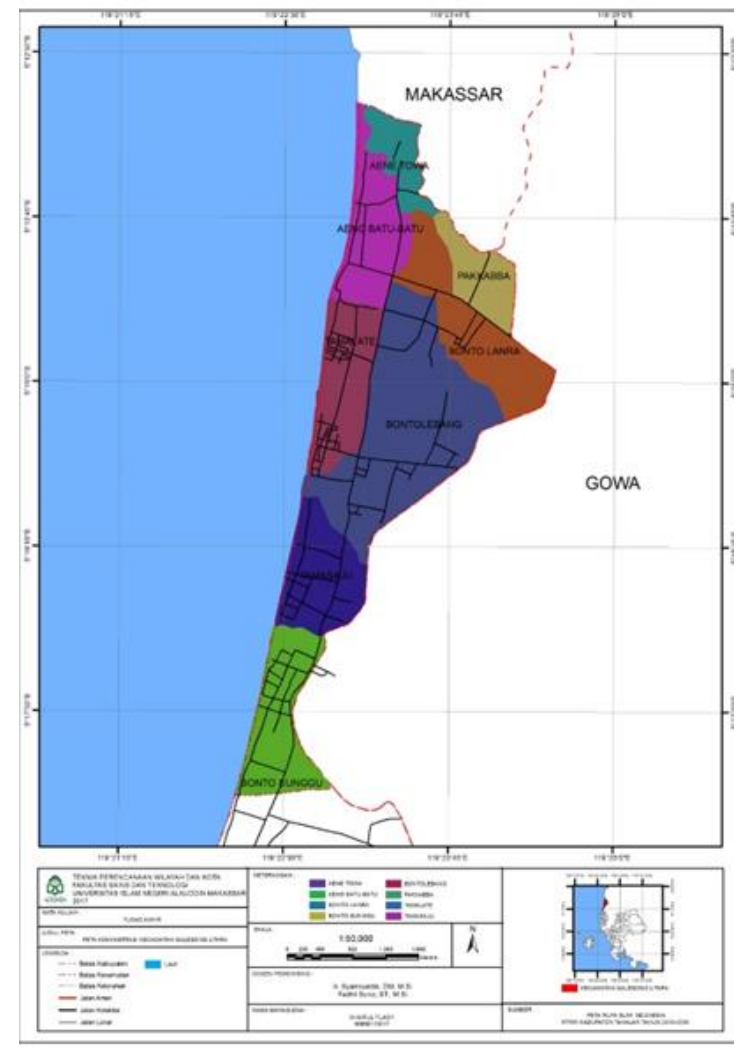

Gambar 3. Peta Kecamatan Galesong Utara

Jumlah penduduk Kecamatan Galesong Utara pada tahun 2016 sekitar 39.228 jiwa, yang terdiri dari 19.210 laki-laki dan 20.018 jiwa perempuan. Dari jumlah tersebut, Kelurahan Bonto Lebang adalah terbesar jumlah penduduknya sekitar 5.743 jiwa dan Desa yang paling kecil jumlah penduduknya adalah Desa Bonto Kaddopepe sekitar 1.580 jiwa.

\section{Hubungan Terhadap Budidaya Perikanan}

Kawasan budidaya perikanan yang diusahakan oleh masyarakat setempat berupa kegiatan pertambakan. Luas lahan tambak pada tahun 2016 mengalami penurunan dibandingkan dengan lahan tambak pada tahun 2015. Hubungan perkembangan lahan terbangun terhadap kegiatan budidaya perikanan ditampilkan pada Tabel 1. 
Tabel 1. Hubungan keterkaitan antara kawasan budidaya tambak dengan dampak pembangunan kawasan bisnis dan wisata terpadu

\begin{tabular}{|l|l|l|c|c|c|}
\hline \multirow{2}{*}{ Tahun } & $\begin{array}{l}\text { Tamba } \\
\mathrm{k}(\mathrm{ha})\end{array}$ & $\begin{array}{c}\text { Lahan } \\
\text { Terbang } \\
\text { un (ha) }\end{array}$ & $\mathrm{x} 2$ & $\mathrm{y} 2$ & $\mathrm{xy}$ \\
\cline { 2 - 5 } & $\mathrm{x})$ & $\mathrm{y})$ & & & \\
\hline 2014 & 156 & 877.61 & 24336 & 770199.31 & 136907.16 \\
2015 & 156 & 877.61 & 24336 & 770199.31 & 136907.16 \\
2016 & 146 & 878.32 & 21316 & 771446.02 & 128234.72 \\
\hline Jumlah & 458 & 2633.54 & 69988 & 2311844.6 & 402049.04 \\
\hline
\end{tabular}

Sumber : hasil analisis, 2018

Diketahui:

$\begin{array}{ll}\mathrm{N} & =3 \\ \sum x & =458 \\ \sum y & =2.633,54 \\ \sum x y & \quad=402.049,04 \\ \sum x^{2} & =69.988 \\ \left(\sum x\right)^{2} & =209.764 \\ \sum y^{2} & =2.311 .844,647 \\ \left(\sum y\right)^{2} & =6.935 .532,9316\end{array}$

Penyelesaian:

$$
\begin{aligned}
r & =\frac{N \cdot \sum x y-\sum x \cdot \sum y}{\sqrt{\left[N \cdot \sum x^{2}-\left(\sum x\right)^{2}\right]\left[N \cdot \sum y^{2}-\left(\sum y\right)^{2}\right]}} \\
r & =\frac{-14.2}{141,0644534} \\
r & =-1.006632051
\end{aligned}
$$

Dari hasil analisis uji korelasi kawasan budidaya perikanan terhadap lahan terbangun di Kecamatan Galesong Utara diperoleh nilai $r$ adalah 1.006632051 maka menunjukkan tidak ada hubungan. Sehingga dapat diinterpretasikan bahwa pengembangan kawasan bisnis dan wisata terpadu di Kota Makassar tidak memiliki kaitan dengan berkurangnya lahan tambak di Kecamatan Galesong Utara.

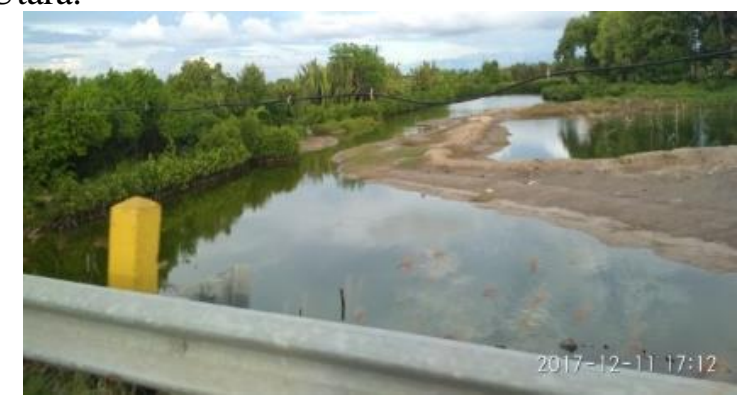

\section{Gambar 4. Lahan tambak}

\section{Pengaruh Terhadap Jumlah Nelayan}

Berdasarkan data dari Dinas Kependudukan setempat diperoleh data berdasarkan mata pencaharian yang berkaitan langsung dengan aktivitas pesisir yaitu nelayan. Jumlah nelayan di Kecamatan Galesong Utara nampak mengalami penurunan, dari 17.340 jiwa di tahun 2015 menjadi 15.547 jiwa di tahun 2016. Hubungan perkembangan lahan terbangun terhadap kegiatan jumlah nelayan ditampilkan pada Tabel 2 .

Tabel 2. Hubungan keterkaitan antara jumlah

\begin{tabular}{|c|c|c|c|c|c|}
\hline \multirow[t]{2}{*}{ Tahun } & Nelayan & \begin{tabular}{|c|}
$\begin{array}{c}\text { Lahan } \\
\text { Terbangun } \\
\text { (ha) }\end{array}$ \\
\end{tabular} & \multirow[t]{2}{*}{$x^{2}$} & \multirow[t]{2}{*}{$y^{2}$} & \multirow[t]{2}{*}{ xy } \\
\hline & $(\mathrm{x})$ & $(\mathrm{y})$ & & & \\
\hline 2014 & $16.95 \mathrm{~s}$ & 877.61 & 287607681 & 770199.3 & 14883387.95 \\
\hline 2015 & 17.340 & 877.61 & 300675600 & 770199.3 & 15217757. \\
\hline 2016 & 15.547 & 878.32 & 241709209 & 771446.0 & 13655241.0 \\
\hline $\mathrm{Jml}$ & 49.846 & 2633.54 & 829992490 & 2311844.6 & 43756386.43 \\
\hline
\end{tabular}
nelayan dengan dampak pembangunan kawasan bisnis dan wisata terpadu

Sumber : hasil analisis, 2018

Diketahui:

$$
\begin{array}{ll}
\mathrm{N} & =3 \\
\sum x & =49.846 \\
\sum y & =2.633,54 \\
\sum x y & =43.756,38643 \\
\sum x^{2}=829,99249 \\
\left(\sum x\right)^{2} & =2.484,62372 \\
\sum y^{2}=2.311 .844,647 \\
\left(\sum y\right)^{2} & =6.935 .532,9316
\end{array}
$$

Penyelesaian:

$$
\begin{aligned}
& r=\frac{N \cdot \sum x y-\sum x \cdot \sum y}{\sqrt{\left[N \cdot \sum x^{2}-\left(\sum x\right)^{2}\right]\left[N \cdot \sum y^{2}-\left(\sum y\right)^{2}\right]}} \\
& r=\frac{-2275.55}{2313.817839} \\
& r=-0.98346117
\end{aligned}
$$

Dari hasil analisis uji korelasi jumlah nelayan terhadap lahan terbangun dimana nilai $\mathrm{r}$ adalah 0.98346117 maka menunjukkan tidak saling berhubungan. Kondisi ini juga menunjukkan bahwa tidak ada keterkaitan antara dampak pembangunan kawasan bisnis dan wisata terpadu terhadap jumlah orang yang bekerja sebagai nelayan di Kecamatan Galesong Utara. Mereka tetap beraktivitas mengelola lahan yang tersisa sebagai kegiatan budidaya perikanan.

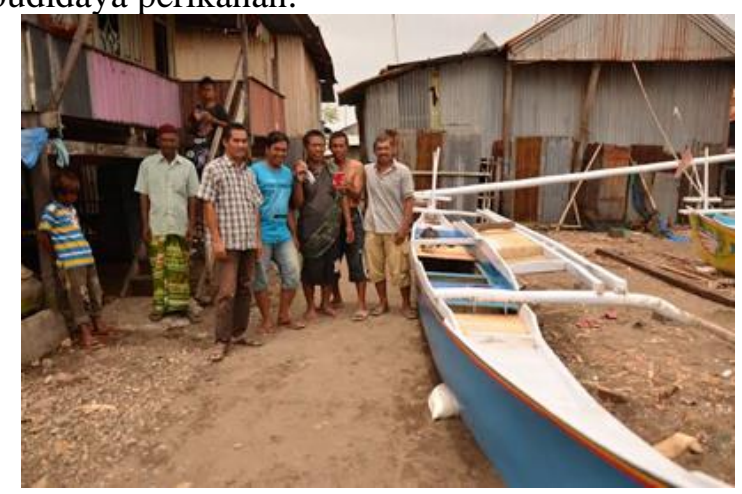

Gambar 5. Aktivitas masyarakat nelayan

Hubungan Terhadap Perdagangan dan Jasa 
Hubungan Pengembangan Kawasan Bisnis Dan Pariwisata Terpadu Di Kota Makassar Terhadap Kawasan Pesisir

Kecamatan Galesong Utara Kabupaten Takalar

Berdasarkan hasil obersvasi di lapangan maka diperoleh data jumlah sarana perdagangan dan jasa di Kecamatan Galesong Utara mengalami kenaikan yang cukup tinggi dari 803 di tahun 2014, 861 di tahun 2015, menjadi 864 di tahun 2016. Hubungan kedunya disajikan pada Tabel 3.

Tabel 3. Hubungan keterkaitan antara perdagangan dan jasa dengan dampak pembangunan kawasan bisnis dan wisata terpadu

\begin{tabular}{|l|r|r|r|r|r|}
\hline \multirow{2}{*}{ Tahun } & Jumlah & $\begin{array}{c}\text { Lahan } \\
\text { Terbangun } \\
\text { (ha) }\end{array}$ & x2 & y2 & xy \\
\cline { 2 - 3 } & \multicolumn{1}{c|}{$(\mathrm{x})$} & \multicolumn{1}{c|}{ (y) } & & & \\
\hline 2014 & 803 & 877.61 & 64480 & 770199.31 & 704720.83 \\
2015 & 861 & 877.61 & 74132 & 770199.31 & 755622.21 \\
2016 & 86 & 878.32 & 74649 & 771446.02 & 758868.48 \\
\hline Jml & 2526 & 2633.54 & 213262 & 2311844.6 & 2219211.52 \\
\hline
\end{tabular}

Sumber : hasil analisis, 2018

Diketahui:

$\begin{aligned} \mathrm{N} & =3 \\ \sum x & =2.528 \\ \sum y & =2.633 .54 \\ \sum x y & =2.219 .211,52 \\ \sum x^{2} & =2.132 .626 \\ \left(\sum x\right)^{2} & =6.390,784 \\ \sum y^{2} & =2.311 .844,647 \\ \left(\sum y\right)^{2} & =6.935 .532,9316\end{aligned}$

Penyelesaian:

$$
\begin{aligned}
r & =\frac{N \cdot \sum x y-\sum x \cdot \sum y}{\sqrt{\left[N \cdot \sum x^{2}-\left(\sum x\right)^{2}\right]\left[N \cdot \sum y^{2}-\left(\sum y\right)^{2}\right]}} \\
r & =\frac{45.44}{84.21990145} \\
r & =0.539539933
\end{aligned}
$$

Dari hasil analisis uji korelasi jumlah sarana perdagangan dan jasa dan dampak pengembangan kawasan bisnis dan wisata terpadu di Kota Makassar diperoleh nilai $\mathrm{r}$ adalah 0.539539933 maka menunjukkan pengaruh yang kuat. Semakin meningkatnya luas lahan terbangun sebagai dampak dari kawasan bisnis dan pariwisata terpadu maka semakin tinggi pula aktivitas perdagangan dan jasa di Kecamatan Galesong Utara.

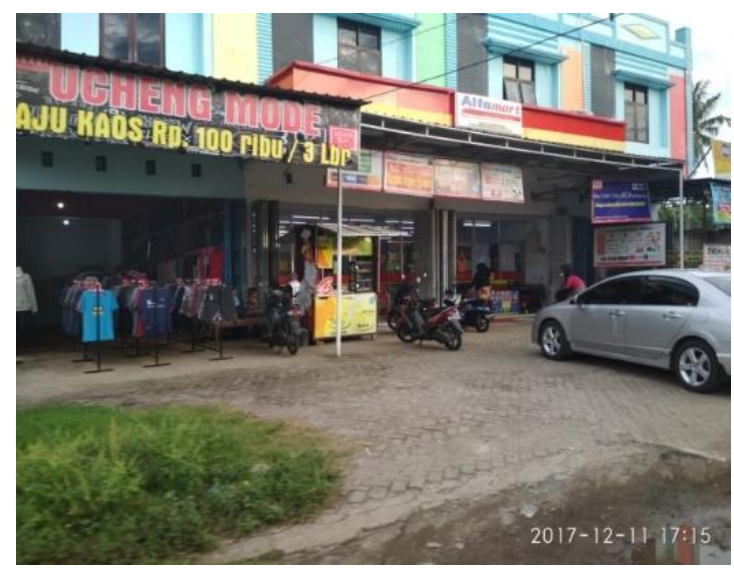

Gambar 6. Perdagangan/jasa

\section{Hubungan Terhadap Prasarana Jalan}

Prasarana jalan di Kecamatan Galesong Utara mengalami penambahan total panjang jalan, dari $85.37 \mathrm{~km}$ di tahun 2014-2015 menjadi $91.16 \mathrm{~km}$ di tahun 2016. Perkembangan prasarana jalan dihitung berdasarkan jumlah panjang pertambahan jalan yang dibangun di Kecamatan Galesong Utara. Hubungan antara perkembangan lahan terbangun terhadap prasarana jalan disajikan pada Tabel 4.

Tabel 4. Hubungan keterkaitan antara prasarana jalan dengan dampak pembangunan kawasan bisnis dan wisata terpadu

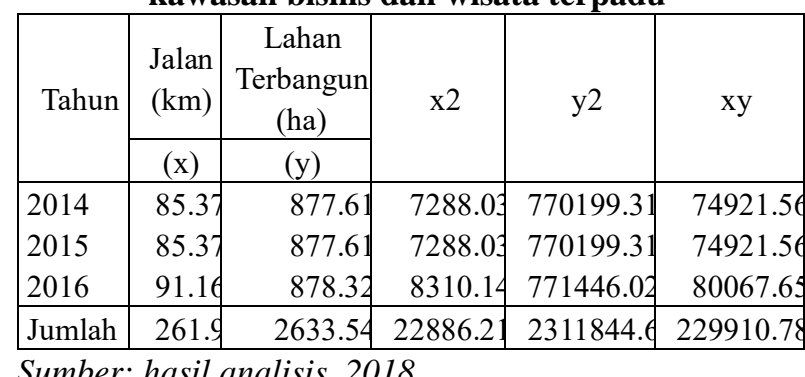

Diketahui:

$$
\begin{aligned}
& \mathrm{N}=3 \\
& \sum x \quad=261.9 \\
& \sum y=2633.54 \\
& \sum x y=2.299 .10,7826 \\
& \sum x^{2} \quad=2.288 .6,2194 \\
& \left(\sum x\right)^{2} \quad=68.591,61 \\
& \sum y^{2} \quad=2.311 .844,647 \\
& \left(\sum y\right)^{2}=6.935 .532,9316
\end{aligned}
$$

Penyelesaian:

$$
\begin{aligned}
r & =\frac{N \cdot \sum x y-\sum x \cdot \sum y}{\sqrt{\left[N \cdot \sum x^{2}-\left(\sum x\right)^{2}\right]\left[N \cdot \sum y^{2}-\left(\sum y\right)^{2}\right]}} \\
r & =\frac{8.2218}{8.126499862} \\
r & =1.011727083
\end{aligned}
$$

Dari hasil analisis uji korelasi prasarana terhadap kawasan pesisir galesong utara dimana nilai $r$ adalah 1.011727083 maka menunjukkan pengaruh yang sangat kuat. Semakin berkembangnya kawasan bisnis dan wisata terpadu di Kota Makassar maka semakin tinggi pula pertambahan panjang jalan di Kecamatan Galesong Utara.

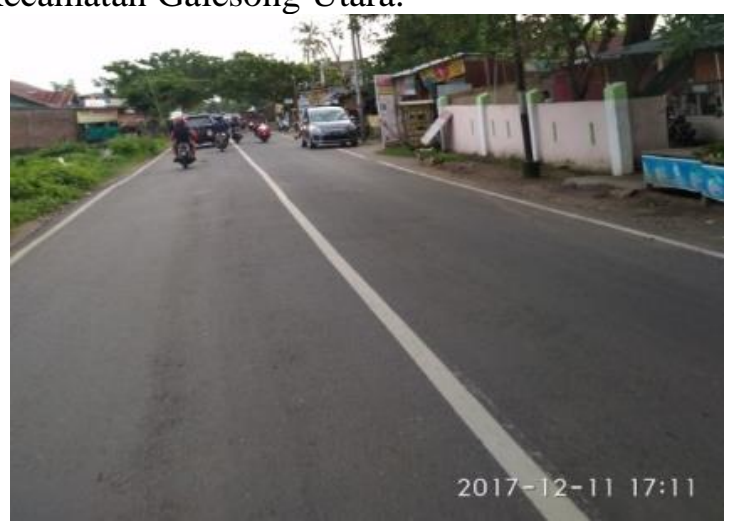

Gambar 7. Kondisi jalan di lokasi penelitian

Berdasarkan 4 variabel yang diukur dapat dirangkum bahwa, varibel yang sangat berpengaruh 
adalah variabel sarana perdagangan/jasa dengan nilai 053 dan prasarana jalan dengan nilai 1.1. Berdasarkan asumsi jika $r=0,5$ atau mendekati 1 maka hubungan kedua variabel sangat kuat atau sangat berpengaruh. Sehingga diindikasikan bahwa pengembangan kawasan bisnis dan wisata terpadu berkaitan dengan adanya penambahan unit sarana perdagangan/jasa dan penambahan panjang jalan.

Tabel 5. Rekapitulasi hubungan 4 variabel kawasan pesisir dengan dampak pembangunan kawasan bisnis dan wisata terpadu

\begin{tabular}{|l|l|c|l|}
\hline No. & \multicolumn{1}{|c|}{ Variabel } & Hasil Analisis & Keterangan \\
\hline 1 & $\begin{array}{l}\text { Kawasan Budidaya } \\
\text { Perikanan }\end{array}$ & -1.006632051 & $\begin{array}{l}\text { Tidak ada } \\
\text { pengaruh }\end{array}$ \\
\hline 2 & Jumlah Nelayan & -0.98346117 & $\begin{array}{l}\text { Tidak ada } \\
\text { pengaruh }\end{array}$ \\
\hline 3 & $\begin{array}{l}\text { Sarana erdagangan } \\
\text { dan Jasa }\end{array}$ & 0.539539933 & $\begin{array}{l}\text { Sangat } \\
\text { Berpengaruh }\end{array}$ \\
\hline 4 & Prasarana Jalan & 1.011727083 & $\begin{array}{l}\text { Sangat } \\
\text { Berpengaruh }\end{array}$ \\
\hline
\end{tabular}

\section{Kesimpulan}

Berdasarkan uraian pembahasan uji korelasi dari 4 varibel yang diukur dapat diinterpretasikan bahwa antara variabel luas lahan tambak, jumlah nelayan, jumlah sarana perdagangan/jasa dan jumlah panjang jalan, hanya jumlah sarana/jasa serta penjang jalan yang memiliki hubungan yang kuat antara dampak pengembangan kawasan wisata dan bisnis di Kota Makassar terhadap kawasan pesisir di Kecamatan Galesong Utara. Hal ini juga menunjukkan bahwa semakin cepatnya terjadi perkembangan kota, tidak mempengaruhi karakter masyarakat setempat sebagai masyarakat nelayan. Walaupun terjadi perubahan fisik di lingkungan mereka

\section{Daftar Pustaka}

1) Yoeti. Oka. Edisi Revisi 1996. Pengantar Ilmu Pariwisata. Bandung: Penerbit Angkasa

2) Ali, Da'faf. 2004. Pemanfaatan Potensi Sumberdaya Pantai sebagai Obyek Wisata dan Tingkat Kesejahteraan Masyarakat Sekitar Lokasi Wisata (Studi Kasus di Kawasan Wisata Pantai Kartini Jepara). Tesis. Program Studi Magister Manajemen Sumberdaya Pantai. Universitas Diponegoro. Semarang.

3) Alim Sumarno. 2012. Perbedaan Penelitian dan Pengembangan

4) Alister Mathieson and Geoffrey Wall. 1982. Tourism: Economic, Physical and Social Impact. New York. Longman Scientific and Technical

5) Dahuri. R. 1993. Daya Dukung Lingkungan dan Pengembangan Pariwisata Berkelanjutan. Paper

6) Dinas Pariwisata Kota Makassar. RIPPDA Kota Makassar 2015-2035. Makassar: Dinas Pariwisata Kota Makassar, 2015.
7) Djunaedi, Achmad. 2011. Perencanaan Pengembangan Kawasan Pesisir. Jurnal Teknologi Lingkungan 3.3.

8) Fahmi. Irham. 2013. Manajemen Strategis Teori dan Aplikasi. Cetakan 1. Bandung: ALFABETA.

9) Greenwood. C.T. 1976. Starch di dalam Y. Pomeranz. Advances in Cereal Science and Technology. AACC. Minnesota.

10) Gunn. A. Clare. 1994. Tourism Planning: Basics. Conc epts. Cases/Third Edition. Taylor \& Francis Ltd. UK.

11) Hardianti. 2014. Pelaksanaan Pengembangan Kawasan Bisnis dan Pariwisata Terpadu Berdasarkan RT/RW Kota Makassar. Skripsi Fakultas Hukum Universitas Hasanuddin.

12) Idha, Wijaya, Nirmalasari. 2007. Analisis Kesesuaian Lahan dan Pengembangan Kawasan Perikanan Budidaya di Wilayah Pesisir Kabupaten Kutai Timur. Tesis (Tidak dipublikasikan). Sekolah Pascasarjana Institut Pertanian Bogor. Bogor.

13) J.R. Brent Ritchie and Charles R. Goeldner (ed.). 1987. Travel, Tourism and Hospitality Research. New York. John Wiley and Sons Inc.

14) K. Lubis, Suhrawardi dan Farid Wajdi. 2012. Hukum Ekonomi Islam. Jakarta: Sinar Grafika.

15) Mamang Sangadji. Etta dan Sopiah. 2010. Metodologi Penelitian. Penerbit Andi: Yogyakarta.

16) Marpaung. Happy dan Bahar Herman. 2002. Pengantar Pariwisata. Bandung : Alfabeta.

17) Michael E. Porter. 2007. Strategi Bersaing (competitive strategy). Tangerang: Kharisma Publishing Group.

18) Pendit. Nyoman S. 2003. Ilmu Pariwisata Sebuah Pengantar Perdana. Jakarta : Pradniya Paramita.

19) Purnamasari. L. 2009. Pengelolaan Wilayah Pesisir Secara Terpadu dan Berkelanjutan yang Berbasis Masyarakat. Jurnal Lingkungan Hidup.

20) Rangkuti. Freddy (2004). Analisis SWOT Teknik Membedah Kasus Bisnis. PT. Gramedia Pustaka Utama: Jakarta.

21) Riyaningtyas. Mifta Damai. 2014. Strategi pengembangan daerah pesisir pantai sebagai objek pariwisata di kabupaten pacitan. Fakultas Ilmu Sosial Universitas Negeri Yogyakarta.

22) Spillane. JJ. 1994. Pariwisata Indonesia. Siasat Ekonomi dan Rekayasa Kebudayaan. Yagyakarta: Penerbit Kanisius.

23) Sugiyono 2001. Metode Penelitian Administrasi. Penerbit Alfabeta: Bandung. 
24) Wiwoho. B.dkk. 1990. Pariwisata Citra

dan Manfaatnya. Jakarta: PT. Bina Rena

Pudjawati 